\title{
The Analysis of Circumfix (ka-an) in Minang Language Subdistrict Sei Geringging Pariaman
}

\author{
Adrallisman 1)* \\ ${ }^{1)}$ Universitas Buddhi Dharma \\ Jl. Imam Bonjol No.41. Karawaci Ilir, Tangerang, Indonesia \\ 1)adralisman@ubd.ac.id
}

Article history:

Received 10 May 2021;

Revised 12 May 2021;

Accepted 13 May 2021;

Available online 15 May 2021

Keywords:

Affix

Morphological

Derrivational

\begin{abstract}
The aim of the research is to give the description of circumfix ( ka-an) in Minang Language subdistrict Sei Geringging Pariaman. This is descriptive qualitative research. The steps in collecting data are: reading and underlying sentences that contains affixes and classifying the class. The collected data are analyzed by using morphological theory by Bauer (1988). The result of the analysis reveals that circumfix (ka-an) in Minang Language subdistrict Sei Geringging Pariaman could be used with the base form of noun, verb and adjective. Some of them change the class of words (derrivational) and some of them keep the same class of word (inflectional).
\end{abstract}

\section{INTRODUCTION}

Indonesia is nation unity that consists of thousands of island with different tribe and different language. The consequences is each region of Indonesia has its own language eventhough the inhabitants use Indonesian as the national language that can be understood by all Indonesia population. One of the region is Sei Geringging in Pariaman.

Affixes get much involve in daily communication because almost all of the words facing the affixation. One of the example of affixation in Indonsian language is circumfix ( $\mathrm{ke}-\mathrm{an}$ ). This kinds of affix can be used with the base form of word. When it is used in the word, it can change the word class and also it can change the grammatical meaning. British Dictionary definitions for grammatical meaning is the meaning of word by reference to its function within a sentence rather than to a word outside the sentence.

Circumfix (ka-an) in Minang Language subdistrict Sei Geringging Pariaman can be used with some base form of the word. The combination circumfix $(\mathrm{ka}-\mathrm{an})$ and the base form of the word influence the grammatical meaning of the base form. Therefore, it is something unique to do the research about the circumfix (ka - an) that can change the word class.

The writer chooses the language of minang kabau that is used in subdistrict Sei Geringging Pariaman because Sei Geringging is one of the district that has the unique language that is much diffrent from the other subdistrict especially for the use of phatic language such as 'nyeh', 'yeh', 'yuia', 'e', etc. The writer hopes that this research can be useful for the the development of minangkabau language especially minang language used in Sei Geringging Pariaman.

\section{RELATED WORKS}

\section{Morphology}

Language as a mean of communication has it own structure. It consists of rule and certain formula. The change in word class can be applied in diferent words. This kinds of rules and formula is covered by the term of Morphology. (McCarthy, 2002) state that morphology is the area of grammar concerned with the structure of words and with relationships between words involving the morphemes that compose them is technically called, from the Greek word morphe 'form, shape'; and morphemes can be thought of as the minimal units of morphology. In addition, (Todd, 1987) give the meaning of morphology is the study of morphemes, which are the smallest significant units of grammar. While (Fromkin, 2000) claims that Morphology is the study of words and their structure. What is a word?

\footnotetext{
${ }^{*}$ Corresponding author
} 
Words are meaningful linguistics units that can be combined to form phrases and sentences. When a speaker hears a word in his language, he has an immediate association with a particular meaning.

\section{Derrivational Morphology}

According to (Todd, 1987) derrivational morphology is the addition of morpheme that can form new word. For example, beauty become beautiful; danger become dangerous.

(Bauer, 1988) convey that if we add the affix $-\mathrm{s}$ to the form car to give car $+\mathrm{s}$, we have started out with the noun and finished up with a noun. There is thus a sense in which we have not changed the part of speech or the category of the base in the affixation process. In contrast, if we add -al to the form person to give personal we have chenged into an adjective in the process of affixation, and so we have changed the category.

(McCarthy, 2002) argued that perform, performs and performed were grammatically conditioned variants of one lexeme perform, but performance was not one of these variants. The reason was that, whereas there are grammatical factors that determine the choice between perform, performs and performed (in appropriate contexts), there is no grammatical factor that requires specifically the presence of -ance on performance. To put it another way: there are contexts where, if any verb appears, it must carry the third person singular suffix -s, but there are no contexts where, if a noun appears, it must carry the suffix -ance. The suffix -ance is not one of the small class of suffixes (so-called 'inflectional' suffixes) whose use is tightly determined by grammar. What sort of suffix is it, then? A short answer is that, not being inflectional, it must be derivational.

\section{Inflectional Morphology}

(Todd, 1987) declares that inflectional morphology never involve a change of class. Inflectional morphology occurs with noun, pronouns and verbs. In nouns, inflection marks plurality in regular nouns.

For example: book - books

$$
\text { Chair - chairs }
$$

Correspondingly to Todd, (Bauer, 1988) says that all inflectional affixes have a regular meaning, while not all derivational affixes do. While (McCarthy, 2002) explains inflectional morphology or inflection (the topic of this chapter) deals with the inflected forms of words, that is the kind of variation that words exhibit on the basis of their grammatical context. (McCarthy, 2002) says the unusual nouns scissors and pants provide an opportunity to deal with a possible doubt concerning whether the singular-plural contrast in nouns really deserves to be called inflectional.

\section{Affixes}

(Bauer, 1988) proposes that the most common way of building new words in the languages of the world is by using affixes. The commonest type of affix by far is suffix. There are several languages in the world which use suffixes to the exclusion of any other type of affix. According to Bauer there six types of affixes: suffixes, preffixes, circumfixes, infixes, interfixes and transfixes.

(McCarthy, 2002) explains that of the non-root morphemes in the words that we have looked at so far, those that precede the root (like en- in enlarge) are called prefixes, while those that follow it are called suffixes (like -ance in performance, -ness in whiteness, and -able in readable). We have encountered far more suffixes than prefixes, and that is not an accident: there are indeed more suffixes than prefixes in English. An umbrella term for prefixes and suffixes (broadly speaking, for all morphemes that are not roots) is affix. Only root morphemes can be free, so affixes are necessarily bound. We have already noticed that the morphemes -ful and -ness of helpfulness cannot stand on their own. It is easy for anyone who is a native speaker of English to check that the same is true of all the morphemes that I have identified as prefixes and suffixes in (1a) - that is, all the morphemes in these words other than the roots.

\section{The Purpose of the Research}

In reference to the background of the research said above, the purpose of this research is to find out the description of circumfix ( ka - an) in Minang Language subdistrict Sei Geringging Pariaman.

\section{The Significance of the study}

The result of this research is expected to:

1. Enrich the research about the affixes.

2. To give information to the reader about the circumfix ( $\mathrm{ka}-\mathrm{an}$ ) in minang language.

3. To motivate the other research to research the affixation. 


\section{The Limitation of the Problem}

The writer limit the research on circumfix (ka-an) in Minang Language subdistrict Sei Geringging Pariaman. In order to get the data, the writer selects the housing complex and market which was inhabited by people who are originally from Sei Geringging Padang Pariaman. Thus, the writer can ensure communities around the housing complex or the market can serve as informants and as respondents.

\section{METHODS}

\section{Research Methodology}

Research methodology is a way to systematically solve the research problem. It may be understood as a science of studying how research is done scientifically. In it, we study the various steps that are generally adopted by a researcher in studying his research problem along with the logic behind them. It is necessary for the researcher to know not only the research methods/techniques but also the methodology. Researchers not only need to know how to develop certain indices or tests, how to calculate the mean, the mode, the median or the standard deviation or chisquare, how to apply particular research techniques, but they also need to know which of these methods or techniques, are relevant and which are not, and what would they mean and indicate and why. Researchers also need to understand the assumptions underlying various techniques and they need to know the criteria by which they can decide that certain techniques and procedures will be applicable to certain problems and others will not (Kothari, 2004).

\section{Research Method}

The writer uses the descriptve method. According to (Walliman, 2011) descriptive method is the method that relies on observation as a means of collecting data. It attemps to examine situations in order to establish what is the norm, i.e. what can be predicted to happen again under the same circumstances. 'Observation' can take many forms. Depending on the type of information sought, people can be interviewed, questionnaires distributed, visual record made, even sounds and smells recorded.

\section{Collecting Technique}

(Walliman, 2011) argued that there are several basic methods used to collect prymary data. They are: asking questions, conducting interview, observing without gettimng involve, immersing oneself in a situation, doing experiments and manipulating models.

\section{Conducting Interviews}

In this research the data that the writer get is from interview. According to the writer opinion, by doing the interview, the writer get the data directly and precisely. As (Walliman, 2011) said that interviews are more suitable for questions that require probing to obtain adequate information. There are three types of interview, they are:

1. Structure interview-standardized questions read out by the interviewer according to an interview schedule. Answer may be closed format.

2. Unstructured interview-a flexible format, usually based on a question guide but where the format remains the choice of the interviwer, who can allow the interview to 'ramble' in order to get insights into the attitudes of the interviewee.

3. Semi-structrued interview-one of the contains structured and unstructured sections with stsndardized and open type question.

\section{Observing without Getting Involve}

This is a method of gathering data through observation rather tha asking questions. The aim is to take a detached view of the phenomena, and be 'invisible', either in fact or in effect (i.e. by being ignored by people or animals). When studying humans or animals, this detachment assumes an absence of involvement in the group even if the subjects are aware that the observation is taking place.

Observation can be used for recording data about events and activities, and the nature or conditions of objects, such as buildings or artefacts. This type of observation is often referred to as a survey (not to be COLLECTING PRIMARY DATA 101 confused with a questionnaire survey), and can range from a preliminary visual survey to a detailed survey using a range of instruments for measurement (Walliman, 2011). 


\section{The Techniques of Data Analysis}

The data that were been collected are analyzed in other to be processed. The data are analyzed by the following step:

1. Transcribing the spoken data into words.

2. Calasifying the data into circumfix.

3. Analyzing the process of forming circumfix.

4. Concluding the result of analysis

5. Formalizing the research finding.

\section{RESULTS}

\section{The circumfix (ka-an) in Sei Geringging Pariaman}

Circumfix (ka-an) in Minangkabau language in Sei Geringging Pariaman can be used with the base form of noun, verb and adjective. The following are the process of combining circumfix (ka-an) with the base form of noun, verb and adjective.

1. Circumfix (ka-an) with noun.

For example:

'nagari' (noun) + circumfix (ka-an) become 'kanagarian' (adjective).

The use of circumfix (ka-an) and base form of noun 'nagari' become 'kanagarian', changes the word class from noun to adjective.

2. Circumfix (ka-an) with verb.

For example:

'pai' (verb) + circumfix (ka-an) become 'kapaian' (noun).

The use of circumfix (ka-an) and base form of verb 'pai' become 'kapaian', changes the word class from verb to noun.

3. Circumfix (ka-an) with adjective.

For example:

'ongah' (adjective) + circumfix (ka-an) become 'kaongahan' (noun).

The use of circumfix (ka-an) and base form of adjective 'ongah' become 'kaongahan', changes the word class from adjective to noun.

\section{Grammatical meaning circumfix (ka-an) in Sei Geringging Pariaman}

Grammatical meaning is the meaning of a word by reference to its function within a sentence rather to a world outside the sentence.

1. The use of circumfix (ka-an) with the base form of adjective that generates the meaning of too much. The following is the example of the word in the sentence.

Ubek e ditokok kaaluihan :The medicine is concocted too smooth.

In the sentence above, the bold word 'kaaluihan' is derived from the base form of adjective 'aluih' that means smooth. In the combination of circumfix and the word, the meaning become too much.

2. The use of circumfix (ka-an) with the base form of adjective that generates the meaning of the result. The following are the sopken data.

Ibo hati e dek kakalahan tim e : She is sad because of the defeat of her tim.

In the sentence above, the bold word 'kakalahan' is derived from the base form of adjective 'kalah' that means lost. However, in the combination, the meaning become the result of the game.

3. The use of circumfix (ka-an) with the base form of adjective that generates the meaning of genital. The following are the sopken data.

Inyo gilo moh, kamaluan e nampak je : He is crazy, his genital has not been covered.

The bold word in the sentences, 'kamaluan' is derived from the base form of adjective 'malu' that means shy. Because of the use of circumfix, the meaning is change to his genital.

4. The use of circumfix (ka-an) with the base form of adjective that generates the meaning of blown. The example. Ambo kalamehan di dalam gudang : I feel limp in the warehose.

The bold word in the sentences, 'kalamehan' is derived from the base form of adjective 'lemas' that means limp. Because of the use of circumfix with the said word, the meaning is change to blown. 
5. The use of circumfix (ka-an) with the base form of noun that generates the meaning of a group. The following is the example:

Kanagarian malai tigo koto: The region of Mala tigo koto.

The bold word in the sentences, 'kanagarian' is derived from the base form of noun 'nagari' that means district.

Because of the use of circumfix with the said word, the meaning is change to a group.

6. The use of circumfix (ka-an) with the base form of adjective that generates the meaning of feeling. The example:.

Inyo kacamehan je : She is always worry.

The bold word in the sentences, 'kacamehan' is derived from the base form of adejective 'cameh' that means worry. Because of the use of circumfix with the said word, the meaning is change to feeling of worry.

7. The use of circumfix (ka-an) with the base form of noun generates the meaning of imperative. The following is the sentence.

Kaluwaan kunci tu : Take the key off.

The bold word in the sentences, 'kaluwaan' is derived from the base form of noun 'luwa' that means utside. Because of the use of circumfix with the word, the meaning is change to imperative word.

8. The use of circumfix (ka-an) with the base form of adjective generates the meaning of ability. The example:.

Ado-ado je kapandaian ne : He can do everything.

The bold word in the sentences, 'kapandaian' is derived from the base form of adjective 'pandai' that means smart. Because of the use of circumfix with the word, the meaning is changed to the ability.

\section{CONCLUSIONS}

After doing the analysis, the writer come to the conclusion that circumfix (ka-an) Minang Language Subdistrict Sei Geringging Pariaman could be used with the base form of noun, verb and adjective. Some of them change the word class (derrivational) and some of them keep the word class the same Inflectional).

And the use of circumfix (ka-an) in Minang Language Subdistrict Sei Geringging Pariaman generates diferent meaning. Namely:

a. generating the meaning of too much.

b. generating the meaning of the result of the game.

c. generating the meaning of genital.

d. generating the meaning of facing difficulty.

e. generating the meaning of a group.

f. generating the meaning of feeling of worry.

g. generating the meaning of imperative.

h. generating the meaning of ability.

\section{REFERENCES}

Bauer, L. (1988). Introducing Lingusitics Morphology. Edinburgh University Press.

Fromkin, V. A. (2000). Linguistics an Introduction to Linguistics Theory. Black well Publisher Inc.

Kothari, C. . (2004). Research Methodology, Methods and techniques. New Age International (P) Ltd., publisher.

McCarthy, A. C. (2002). An Introduction to English Morphology: Words and Their Structure. Edinburgh University Press.

Todd, L. (1987). An Introduction to Linguistics. York Press.

Walliman, N. (2011). Research Methods the Basic. Routledge 2 Park Square, Oxon OX144 RN. 